\title{
Physicochemical characterization of jack bean (Canavalia ensiformis) tempeh
}

\author{
1,*Andriati, N., ${ }^{1}$ Anggrahini, S., ${ }^{1}$ Setyaningsih, W., ${ }^{1}$ Sofiana, I., ${ }^{1}$ Pusparasi, D.A. and \\ ${ }^{2}$ Mossberg, F. \\ ${ }^{1}$ Department of Food Science and Agricultural Product Technology, Faculty of Agricultural Technology, \\ Gadjah Mada University, Jl. Flora No.1 Bulaksumur, Yogyakarta 55281 \\ ${ }^{2}$ Department of Biotechnology, Chalmers University of Technology, Sweden
}

\section{Article history:}

Received: 25 June 2018

Received in revised form: 29

July 2018

Accepted: 16 August 2018

Available Online: 3

September 2018

\section{Keywords:}

Jack bean,

Tempeh,

Physicochemical properties,

Functional properties

DOI:

https://doi.org/10.26656/fr.2017.2(5).300

\begin{abstract}
The objective of our research was to investigate the properties of jack bean tempeh during fermentation with two different packaging types, banana leaves and LDPE (Low-Density Poly Ethylene) Plastic. After 24 hrs mycelia of Rhizopushasnot been formed, but it fully formed after $36 \mathrm{hrs}$ fermentation for all formulated tempeh with two different packaging. The mycelia started the change to form brownish colour after $36 \mathrm{hrs}$ of fermentation. Solid state fermentation (SSF) for 0, 24, 36, 48 and $60 \mathrm{~h}$ showed influence in different parameter e.g. total protein, the colour parameter $(\mathrm{L}, \mathrm{a}, \mathrm{b}, \mathrm{C}, \mathrm{Hue}$, and $\Delta \mathrm{E})$ and $\mathrm{pH}$ during fermentation $(\mathrm{p}<0.05)$. Optimum condition of tempeh was chosen after $36 \mathrm{hrs}$ fermentation that showed the influence of different packaging type to the lipid content and antioxidant activity $(\mathrm{p}<0.05)$, but no significant different to the water content, ash content, protein content, dietary fiber content and carbohydrate by the different content of tempeh ( $>0.05$ ). In the present research work, we demonstrated that different fermentation time and packaging will give influence to several physiochemical characteristics including total soluble protein, colour, and $\mathrm{pH}$.
\end{abstract}

\section{Introduction}

Tempeh is an Indonesian staple food produced through a solid-state fungal fermentation of legumes, resulting to a mycelia-knitted compact cake of beans (Gibbs et al., 2004). The key microorganism leading the process of tempeh production is a fungus from the Rhizopus genus family, which digests the raw materials; thereby increasing its nutritional value for human consumption (Cuevas-Rodríguez et al., 2006; Azeke et al., 2007).

In Indonesian, although tempeh is mostly made from soybeans, it can also be produced from a wide variety of legumes, one of them is jack bean (Canavalia ensiformis). While the use of jack bean for making tempeh is still restricted to few places, especially the Yogyakarta region of Central Java province, it is becoming a potential substitute for soybean across Indonesia, because there is evidence that jack bean tempeh resembles soybean tempeh in many aspects, including color, flavor, texture and overall acceptability (Widaningrum et al., 2012). Additionally, jack bean has potential medicinal value. For example, the methanolic extract of jack bean seeds contains acceptable levels of free phenolics with promising antioxidant and type II diabetes-related enzyme inhibition properties (Vadivel et al., 2012). Moreover, the seed decoction or powdered seeds from jack bean are used as an antibiotic and antiseptic. Furthermore, urease-derived peptide from jack bean represents a new example of the membraneactive peptide with insecticidal and fungi toxic activities (Martinelli et al., 2014). Therefore, a further step towards encouraging the idea that jack bean is a suitable ingredient for tempeh production would be to determine its physicochemical characteristic and functional value. Indeed, several investigations have shown that fermentation especially solid-state fermentation during tempeh production can decrease the physicochemical characteristic and functional value of tempeh, including reduction of value e.g. phytic acid and substance that can cause flatulence (Eklund-Jonsson et al., 2006; Cuevas-Rodríguez et al., 2006; Azeke et al., 2007; Duli and Starzy, 2016). The objective of this study was to investigate the physicochemical characteristic and functional property of jack bean tempeh, by examining the solid-state fermentation of jack bean tempeh under different packaging material (banana leaves and plastic packaging) and fermentation time $(0,24,36,48$ and 60 hrs). 


\section{Materials and methods}

\subsection{Material}

Jack bean (C. ensiformis) seeds-(white color seed coat) were collected from Playen District, GunungKidul, Yogyakarta by the cooperation with UST (Universitas Sarjanawiyata Taman Siswa), Yogyakarta. Commercial tempeh culture was $R$. oligosporus from Raprima Cultures (Indonesia). All chemicals were from Merck, Darmstadt, Germany. The packaging of tempeh e.g. banana leaves and plastic were purchased in a local market.

\subsection{Tempeh production}

The tempeh was made by the addition of starter tempeh (commercial tempeh culture. The tempeh was prepared in the laboratory according to the procedure described by Kustyawati et al. (2017) as follows: First, the jack beans $(300 \mathrm{~g})$ were washed and soaked in clean tap water for $1 \mathrm{hr}$ at room temperature $\left(28^{\circ} \mathrm{C}\right)$, and then boiled for 30 mins; the ratio of water to soybean was $3: 1$. This was followed by dehulling to remove the jack bean skin from the cotyledon manually, and another boiling for 30 mins. Subsequently, the boiled jack beans were drained, air-dried, inoculated with $0.02 \mathrm{~g}$ ragi for every $100 \mathrm{~g}$ cooked jack beans, and packed into the perforated banana leaves and plastic bags, then incubated for 0,24 , 36,48 and $60 \mathrm{hrs}$ at $32^{\circ} \mathrm{C}$. All samples were prepared in duplicates according to Kustyawati et al., (2017).

\subsection{Colour}

The colour was measured with Chroma Meter (Minolta CR 400, Japan). The instrument was calibrated with the white calibration plate before the measurement. The internal color (International Commission on Illumination $\mathrm{L}^{*}, \mathrm{a}^{*}, \mathrm{~b}^{*}$ ) of samples were measured. To determine differences in color values to visually perceived differences, the calculation of $\Delta \mathrm{E}$ was made using the method of Hidayat et al. (2018).

\subsection{Total Soluble Protein}

The soluble protein content was measured by following the Modified Lowry's method (Lowry et al., 1951).

\section{$2.5 \mathrm{pH}$}

Five grams $(5 \mathrm{~g})$ of tempeh were homogenized in 50 $\mathrm{mL}$ of water, and the filtrate was obtained using Whatman filter paper. Then the $\mathrm{pH}$ was measured using a $\mathrm{pH}$ meter that has been calibrated with buffer $\mathrm{pH} 4$ and $\mathrm{pH} 7$

\subsection{Proximate analysis}

Moisture, ash, protein, and fat contents were determined according to the reference methods described by AOAC (AOAC, 1998). Moisture content was determined by oven drying at $105^{\circ} \mathrm{C}$ until constant weight was obtained. Crude fat was determined by the Soxhlet method using ether extraction (AOAC method 4.5.05). Crude protein was analyzed by the Kjeldahl method (AOAC method 960.52). Ash was quantified after burning at $550^{\circ} \mathrm{C}$ for $20 \mathrm{hrs}$ (AOAC method 942.05). The total dietary fiber content (TDF) was evaluated by an enzymatic-gravimetric method (Leão et al., 2017)

\subsection{Antioxidant activity}

The radical scavenging activity against DPPH of the methanolic extract was analyzed for measuring total antioxidant, according to Vadivel et al. (2012) and Kumar et al. (2018). Briefly, methanolic extract sample $(0.1 \mathrm{~mL})$ was added to $3.9 \mathrm{~mL}$ of 2,2-diphenyl-1picrylhydrazyl (DPPH) $\left(6 \times 10^{-5} \mathrm{~mol} / \mathrm{L}\right)$ in methanol and incubated for $30 \mathrm{mins}$ at room temperature $\left(30 \pm 1^{\circ} \mathrm{C}\right)$; then absorbance was measured at $515 \mathrm{~nm}$. DPPH solution was used as the control and methanol was used as the blank.

\subsection{Statistical analysis}

Analysis of variance (ANOVA) was performed using the general linear model in Minitab 17 Statistical Software (Minitab Inc., State College, PA, USA) and Turkey's multiple comparison tests for the parameters of color (L, a, b, C, Hue), total soluble protein, $\mathrm{pH}$, proximate analysis, dietary fiber and antioxidant activity. $\mathrm{p}<0.05$ was considered statistically significant.

\section{Results and Discussion}

3.1 Effect during fermentation time and packaging type on mycelia formation

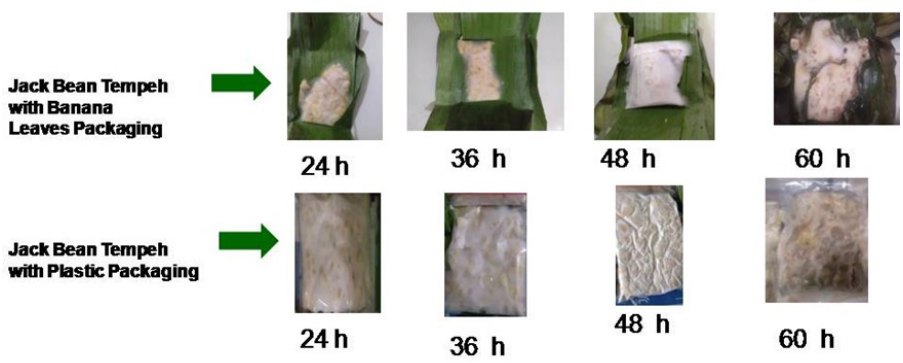

Figure 1. Tempeh after different time of fermentation with two different packaging type

Figure 1 represents the structural appearance of jack bean during fermentation with two different packaging materials and four-time regimes, while Table 1 depicts changes in physiochemical elements resulting from both packaging and incubation time. Accordingly, the growth of mycelia in different packaging showed that tempeh 
Table 1. Physicochemical change of tempeh during fermentation time with different packaging type

\begin{tabular}{|c|c|c|c|c|c|c|}
\hline \multirow{2}{*}{ Parameter } & \multirow{2}{*}{ Packaging Type } & \multicolumn{5}{|c|}{ Fermentation Time (hours) } \\
\hline & & 0 & 24 & 36 & 48 & 60 \\
\hline \multirow{2}{*}{$\begin{array}{l}\text { Total Soluble Protein } \\
(\mathrm{g} / \mathrm{mL})\end{array}$} & Banana Leaves & $0.02 \pm 0.01^{\mathrm{aB}}$ & $0.03 \pm 0.01^{\mathrm{aAB}}$ & $0.04 \pm 0.01 \mathrm{a}^{\mathrm{AB}}$ & $0.03 \pm 0.00^{\mathrm{aA}}$ & $0.03 \pm 0.00^{\mathrm{aB}}$ \\
\hline & Plastic & $0.02 \pm 0 . .^{00 \mathrm{aB}}$ & $0.03 \pm 0.00^{\mathrm{aAB}}$ & $0.03 \pm 0.00^{\mathrm{aAB}}$ & $0.07 \pm 0.00^{\mathrm{aA}}$ & $0.02 \pm 0.00^{\mathrm{aB}}$ \\
\hline \multicolumn{7}{|l|}{ Color } \\
\hline \multirow{2}{*}{ L (Lightness) } & Banana Leaves & $75.2 \pm 0.14^{\mathrm{aCD}}$ & $71.88 \pm 0.01^{\mathrm{aD}}$ & $79.35 \pm 0.01^{\mathrm{aAB}}$ & $81.45 \pm 0.03^{\mathrm{aA}}$ & $72.26 \pm 0.02^{\mathrm{aBC}}$ \\
\hline & Plastic & $75.88 \pm 0.00^{\mathrm{aCD}}$ & $70.18 \pm 0.00^{\mathrm{aD}}$ & $81.45 \pm 0.00^{\mathrm{aAB}}$ & $80.35 \pm 0.00^{\mathrm{aA}}$ & $80.26 \pm 0.00^{\mathrm{aBC}}$ \\
\hline \multirow[b]{2}{*}{$\mathrm{a}$} & Banana Leaves & $1.77 \pm 0.00^{\mathrm{aC}}$ & $1.95 \pm 0.01^{\mathrm{aB}}$ & $4.41 \pm 0.01^{\mathrm{aA}}$ & $4.45 \pm 0.00^{\mathrm{aA}}$ & $4.37 \pm 0.00^{\mathrm{aA}}$ \\
\hline & Plastic & $1.77 \pm 0.00^{\mathrm{bC}}$ & $3.12 \pm 0.00^{\mathrm{bB}}$ & $4.31 \pm 0.00^{\mathrm{bA}}$ & $4.79 \pm 0.00^{\mathrm{bA}}$ & $4.37 \pm 0.00^{\mathrm{bA}}$ \\
\hline \multirow[b]{2}{*}{$b$} & Banana Leaves & $12.53 \pm 0.00^{\mathrm{aB}}$ & $17.65 \pm 0.01^{\mathrm{aA}}$ & $6.04 \pm 0.01^{\mathrm{aCD}}$ & $7.02 \pm 0.00^{\mathrm{aC}}$ & $3.46 \pm 0.00^{\mathrm{aD}}$ \\
\hline & Plastic & $10.46 \pm 0.00^{\mathrm{bB}}$ & $12.33 \pm 0.00^{\mathrm{bA}}$ & $5.24 \pm 0.01^{\mathrm{bCD}}$ & $5.2 \pm 0.01^{\mathrm{bC}}$ & $3.46 \pm 0.01^{\mathrm{bD}}$ \\
\hline \multirow[b]{2}{*}{$\mathrm{C}$} & Banana Leaves & $12.65 \pm 0.00^{\mathrm{aB}}$ & $17.76 \pm 0.00^{\mathrm{aA}}$ & $7.48 \pm 0.00^{\mathrm{aC}}$ & $8.31 \pm 0.01^{\mathrm{aC}}$ & $5.57 \pm 0.03^{\mathrm{aC}}$ \\
\hline & Plastic & $10.61 \pm 0.01^{\mathrm{bB}}$ & $12.72 \pm 0.01^{\mathrm{bA}}$ & $6.78 \pm 0.01^{\mathrm{bC}}$ & $7.07 \pm 0.01^{\mathrm{bC}}$ & $5.57 \pm 0.01^{\mathrm{bC}}$ \\
\hline \multirow{2}{*}{ Hue } & Banana Leaves & $1.43 \pm 0.00^{\mathrm{aA}}$ & $1.46 \pm 0.00^{\mathrm{aA}}$ & $0.94 \pm 0.00^{\mathrm{aB}}$ & $1.01 \pm 0.00^{\mathrm{aB}}$ & $0.67 \pm 0.00^{\mathrm{aC}}$ \\
\hline & Plastic & $1.4 \pm 0.01^{\mathrm{bA}}$ & $1.32 \pm 0.01^{\mathrm{bA}}$ & $0.88 \pm 0.01^{\mathrm{bB}}$ & $0.83 \pm 0.01^{\mathrm{bB}}$ & $0.67 \pm 0.01^{\mathrm{bC}}$ \\
\hline \multirow{2}{*}{$\Delta \mathrm{E}$} & Banana Leaves & $0 \pm 0.00^{\mathrm{aD}}$ & $6.11 \pm 0.00^{\mathrm{aC}}$ & $15.47 \pm 0.00^{\mathrm{aB}}$ & $15.01 \pm 0.00^{\mathrm{aA}}$ & $18.02 \pm 0.00^{\mathrm{aA}}$ \\
\hline & Plastic & $0 \pm 0.01^{\mathrm{bD}}$ & $6.11 \pm 0.01^{\mathrm{bC}}$ & $16.09 \pm 0.01^{\mathrm{bB}}$ & $16.22 \pm 0.01^{\mathrm{bA}}$ & $18.01 \pm 0.01^{\mathrm{bA}}$ \\
\hline \multirow{2}{*}{$\mathrm{pH}$} & Banana Leaves & $6.34 \pm 0.00^{\mathrm{aB}}$ & $6.26 \pm 0.00^{\mathrm{aB}}$ & $6.16 \pm 0.00^{\mathrm{aB}}$ & $6.34 \pm 0.00^{\mathrm{aB}}$ & $7.76 \pm 0.00^{\mathrm{aA}}$ \\
\hline & Plastic & $6.18 \pm 0.00^{\mathrm{aB}}$ & $6.39 \pm 0.00^{\mathrm{aB}}$ & $6.40 \pm 0.00^{\mathrm{aB}}$ & $6.59 \pm 0.00^{\mathrm{aB}}$ & $7.53 \pm 0.00^{\mathrm{aA}}$ \\
\hline
\end{tabular}

Means with small alphabet superscripts within columns, and those with capital alphabet superscripts within rows are significantly different $(\mathrm{p}<0.05)$.

packed with plastic had more compact mycelia than tempeh packed with banana leaves. Different packaging type could influence the growth of mycelia (Sukasih and Purwani, 2015). With respect to fermentation time, formation of brown mycelia started to appear after $36 \mathrm{hrs}$ regardless of the type of packaging material used, which is consistent with the reports by other researchers (Sanberg et al., 2006; Angulo-Bejarano et al., 2008; Azeke et al., 2007; Duli and Starzy, 2016).

\subsection{Effect during fermentation time and packaging type on physicochemical parameters}

\subsubsection{Total soluble protein}

Total soluble protein content in jack bean tempeh showed no significant $(p>0.05)$ difference between different type of packaging used, although there was significant $(\mathrm{p}>0.05)$ difference with respect to fermentation time (Table 1). Similar findings have been reported on nutritional parameters and the in vitro protein and carbohydrates bioavailability in cooked quinoa seeds (Duli and Starzy, 2016). Also, the amino nitrogen concentrations showed a considerable increase between fermentation during tempeh processing, indicating the degradation of peptide bonds by microbial proteases, without large differences between the starters used (Moa et al., 2013).

\section{$3.2 .2 \mathrm{pH}$}

During fermentation, although $\mathrm{pH}$ values changed a little with packaging materials, they increased significantly ( $>00.05)$ with time to over 7 after $60 \mathrm{hrs}$ (Table 1). Indeed, it's well known that fermentation also causes changes in some organic acids such as acetic acid, oxalic acid, citric acid and succinic acid, which will influence the $\mathrm{pH}$, as observed on soybean fermentation using R.oligosporus starter (Vong et al., 2018) or Rhizopus starter (Moa et al., 2013).

\subsubsection{Color}

Based on the data in Figure 1, L value showed no significant difference $(\mathrm{p}>0.05)$ in the packaging influence on the lightness of the sample, whereas the values changed significantly ( $p>0.05)$ over the course of the fermentation process (Table 1). On the other hand, a, $\mathrm{b}, \mathrm{C}$, Hue and $\Delta \mathrm{E}$ values showed significant $(\mathrm{p}>0.05)$ difference with both packaging material and fermentation time (Table 1).

3.2.4 Water, ash, protein, lipid, carbohydrates, antioxidants and dietary fiber

Table 2 shows the moisture, ash, protein, lipid, carbohydrates, antioxidants and dietary fiber contents of jack bean tempeh recovered after $36 \mathrm{hrs}$ fermentation with banana or plastic packaging. It is evident that lipids and antioxidants were affected by the packaging; lipid values were significantly higher $(p>0.05)$ with banana leaves, while antioxidant values were high with plastic packing. We assume that higher lipase activity could be responsible for the increase in the amount of lipid tempeh packed with plastic, while the increase in 
Table 2. Proximate analysis and antioxidant activity of tempeh after $36 \mathrm{hrs}$ fermentation

\begin{tabular}{lccccccc}
\hline Packaging type & Water (\%) & Ash (\%) & Protein (\%) & Lipid (\%) & $\begin{array}{c}\text { Carbohydrate } \\
(\%)\end{array}$ & $\begin{array}{c}\text { Antioxidant } \\
\text { activity (\%) }\end{array}$ & $\begin{array}{c}\text { Dietary fiber } \\
(\%)\end{array}$ \\
\hline Plastic & $62.49 \pm 0.08^{\mathrm{a}}$ & $0.94 \pm 0.01^{\mathrm{a}}$ & $9.86 \pm 0.16^{\mathrm{a}}$ & $1.62 \pm 0.06^{\mathrm{b}}$ & $25.1 \pm 0.30^{\mathrm{a}}$ & $3.59 \pm 0.07^{\mathrm{b}}$ & $0.79 \pm 0.04^{\mathrm{a}}$ \\
Banana Leaves & $61.63 \pm 0.45^{\mathrm{a}}$ & $0.97 \pm 0.03^{\mathrm{a}}$ & $9.64 \pm 0.24 \mathrm{a}$ & $1.75 \pm 0.01^{\mathrm{a}}$ & $26.02 \pm 0.66^{\mathrm{a}}$ & $2.53 \pm 0.15^{\mathrm{a}}$ & $0.75 \pm 0.01^{\mathrm{a}}$ \\
\hline
\end{tabular}

Means with different superscript within the same column/parameter are significantly different $(\mathrm{p}<0.05)$.

antioxidant activity could be due to increased activity of selected microbe enzyme, as demonstrated with fermented soybean by-product (Chan et al., 2018). The other parameter, including water, ash, protein, carbohydrate and dietary fiber did show any no significant difference between tempeh packed with plastic or banana leaves.

\section{Conclusion}

In this study, we demonstrated that different fermentation time and packaging influenced several physiochemical characteristics, including total soluble protein, colour, and $\mathrm{pH}$. The optimum condition for fermentation of jack bean tempeh was chosen after 36 hrs, and the harvested tempeh packed with plastic contains high levels of lipids, whereas tempeh packed with banana leaves contains high levels of antioxidants, indicating that lipid-rich jack bean tempeh and antioxidant-rich tempeh can be produced using banana leaves packaging and plastic packaging, respectively.

\section{Conflict of Interest}

The authors declare no conflict of interest in the manuscript.

\section{Acknowledgement}

The authors wish to thank DIKTI INDONESIA for the grant of PDUPT 2018 130/UN1/DITLIT/DIT-LIT/ LT/2018 for supporting this project. Dr. Pitia Milla, Shizuoka University, Japan is gratefully acknowledged for careful reading of the manuscript and editorial help.

\section{Reference}

Angulo-Bejarano, P.I., Verdugo-Montoya, N.M., Cuevas -Rodríguez, E.O., Milán-Carrillo, J., MoraEscobedo, R., Lopez-Valenzuela, J.A., GarzónTiznado, J.A. and Reyes-Moreno, C. (2008). Tempeh flour from chickpea (Cicer arietinum L.) nutritional and physicochemical properties. Food Chemistry, 106(1), 106-112. http://doi.org/10.1016/ j.foodchem.2007.05.049

AOAC. (1998). Official methods of analysis of the association of analytical chemists. 16th ed. Washington: AOAC.

Azeke, M.A., Fretzdorff, B., Buening-Pfaue, H. and
Betsche, T. (2007). Comparative effect of boiling and solid substrate fermentation using the tempeh fungus (Rhizopus oligosporus) on the flatulence potential of African yambean (Sphenostylis stenocarpa L.) seeds. Food Chemistry, 103(4), 1420 -1425 . http://doi.org/10.1016/ j.foodchem.2006.10.058

Cuevas-Rodríguez, E.O., Verdugo-Montoya, N.M., Angulo-Bejarano, P.I., Milán-Carrillo, J., MoraEscobedo, R., Bello-Pérez, L.A., Garzón-Tiznado, J.A. and Reyes-Moreno, C. (2006). Nutritional properties of tempeh flour from quality protein maize (Zea mays L.). LWT - Food Science and Technology, 39(10), 1072-1079. http:// doi.org/10.1016/j.lwt.2005.07.003

Duli, R. and Starzy, A. (2016). Prolonged tempe-type fermentation in order to improve bioactive potential and nutritional parameters of quinoa seeds. Cereal Science, 71, 116-121. http://doi.org/10.1016/ j.jcs.2016.08.001

Eklund-Jonsson, C., Sandberg, A.-S. and Alminger, M.L. (2006). Reduction of phytate content while preserving minerals during whole grain cereal tempe fermentation. Journal of Cereal Science, 44(2), 154160. https://doi.org/10.1016/j.jcs.2006.05.005

Gibbs, B.F., Zougman, A., Masse, R. and Mulligan, C. (2004). Production and characterization of bioactive peptides from soy hydrolysate and soy-fermented food. Food Research International, 37(2), 123-131. http://doi.org/10.1016/j.foodres.2003.09.010

Hidayat, B.T., Wea, A. and Andriati, N. (2018). Physicocheical, sensory attributes and protein profile by SDS-PAGE of beef sausage substituted with texturized vegetable protein. Food Research, 2(1), 20-31. https://doi.org/10.26656/fr.2017.2(1).106

Kumar, V., Kushwaha, R., Goyal, A., Tanwar, B. and Kaur, J. (2018). Process optimization for the preparation of antioxidant rich ginger candy using beetroot pomace extract. Food Chemistry, 245, 168177. http://doi.org/10.1016/j.foodchem.2017.10.089

Kustyawati, M.E., Nawansih, O. and Nurdjanah, S. (2017). Profile of aroma compounds and acceptability of modified tempeh. International Food Research Journal, 24(2), 734-740.

Leão, D.P., Franca, A.S., Oliveira, L.S., Bastos, R. and Coimbra, M.A. (2017). Physicochemical 
characterization, antioxidant capacity, total phenolic and proanthocyanidin content of flours prepared from pequi (Caryocar brasilense Camb.) fruit by-products. Food Chemistry, 225, 146-153. http://doi.org/10.1016/j.foodchem.2017.01.027

Lowry, O.H. Rosebrough, N.J. Farr, A.L. and Randall, R.J. (1951). Protein measurement with the Folin phenol reagent. Journal of Biological Chemistry, 193 (1), 265-275.

Moa, H., Kariluoto, S., Piironen, V., Zhu, Y., Sanders, M.G., Vincken, J.P., Wolkers-Rooijackers, J. and Nout, M. J. R. (2013). Effect of soybean processing on content and bioaccessibility of folate, vitamin B12 and isoflavones in tofu and tempe. Food Chemistry, 141(3), 2418-2425. http:// doi.org/10.1016/j.foodchem.2013.05.017

Shi, N., Narciso, J.O., Gou, X., Brennan, M.A., Zeng, X.A. and Brennan, C.S. (2017). Manipulation of antioxidant and glycaemic properties of extruded rice based breakfast cereal products using pomelo fruit by-product material. Quality Assurance and Safety of Crops and Foods, 9(4), 489-495. http:// doi.org/10.3920/QAS2017.1084

Vadivel, V., Cheong, J.N. and Biesalski, H.K. (2012). Antioxidant and type II diabetes related enzyme inhibition properties of methanolic extract of an underutilized food legume, Canavalia ensiformis (L.) DC: Effect of traditional processing methods. LWT - Food Science and Technology, 47(2), 255260. http://doi.org/10.1016/j.lwt.2012.01.014

Vong, W.C., Hua, X.Y. and Liu, S.-Q. (2018). Solidstate fermentation with Rhizopus oligosporus and Yarrowia lipolytica improved nutritional and $\mathrm{fl}$ avour properties of okara. LWT - Food Science and Technology, 90, 316-322. http://doi.org/10.1016/ j.lwt.2017.12.050 